\title{
Genetic and migratory evidence for sympatric spawning of tropical Pacific eels from Vanuatu
}

\author{
Robert Schabetsberger ${ }^{1, *}$, Finn Økland ${ }^{2}$, Donna Kalfatak ${ }^{3}$, Ursula Sichrowsky ${ }^{4}$, \\ Meelis Tambets ${ }^{5}$, Kim Aarestrup ${ }^{6}$, Chrysoula Gubili ${ }^{7,10}$, Jane Sarginson ${ }^{7}$, Belgees \\ Boufana $^{7}$, Robert Jehle ${ }^{7}$, Giorgio Dall'Olmo ${ }^{8}$, Michael J. Miller ${ }^{9}$, Alexander Scheck ${ }^{1}$, \\ Roland Kaiser ${ }^{1}$, Graham Quartly ${ }^{8}$ \\ ${ }^{1}$ University of Salzburg, Department of Cell Biology, 5020 Salzburg, Austria \\ ${ }^{2}$ The Norwegian Institute of Nature Research, 7047 Trondheim, Norway \\ ${ }^{3}$ Department of Environmental Protection and Conservation, Port Vila, Vanuatu \\ ${ }^{4}$ University of Innsbruck, Institute of Ecology, 6020 Innsbruck, Austria \\ ${ }^{5}$ University of Tartu, Estonian Marine Institute, 12618 Tallinn, Estonia \\ ${ }^{6}$ Technical University of Denmark, National Institute of Aquatic Resources, 8600 Silkeborg, Denmark \\ ${ }^{7}$ School of Environment and Life Sciences, University of Salford, Salford, M5 4WT, UK \\ ${ }^{8}$ Plymouth Marine Laboratory, Plymouth, PL1 3DH, UK \\ ${ }^{9}$ College of Bioresource Sciences, Nihon University, Kanagawa 52-0880, Japan \\ ${ }^{10}$ Present address: Coordenação de Biodiversidade, Instituto Nacional de Pesquisas da Amazônia, Manaus, 69067-375, Brazil
}

\begin{abstract}
The spawning areas of tropical anguillid eels in the South Pacific are poorly known, and more information about their life histories is needed to facilitate conservation. We genetically characterized 83 out of 84 eels caught on Gaua Island (Vanuatu) and tagged 8 eels with pop-up satellite transmitters. Based on morphological evidence, 32 eels were identified as Anguilla marmorata, 45 as A. megastoma and 7 as A. obscura. Thirteen of these eels possessed a mitochondrial DNA sequence (control region, 527 bp) or nuclear haplotype (GTH2b, 268 bp) conflicting with their species designation. These individuals also had multi-locus genotypes (6 microsatellite loci) intermediate between the species, and 9 of these eels further possessed heterozygote genotypes at species-diagnostic nuclear single nucleotide polymorphisms (SNPs). We classified these individuals as possibly admixed between $A$. marmorata and $A$. megastoma. One $A$. marmorata and 1 A. megastoma migrated 634 and $874 \mathrm{~km}$, respectively, towards the border between the South Equatorial Current and the South Equatorial Counter Current. Both species descended from around $200 \mathrm{~m}$ depth at night to $750 \mathrm{~m}$ during the day. Lunar cycle affected the upper limit of migration depths of both species. The tags remained attached for 3 and 5 mo and surfaced $<300 \mathrm{~km}$ from the pop-up location of a previously tagged A. marmorata pop-up location. A salinity maximum at the pop-up locations corresponding to the upper nighttime eel migration depths may serve as a seamark of the spawning area. The similar pop-up locations of both species and the evidence for admixture suggest that these tropical eels share a sympatric spawning area.
\end{abstract}

KEY WORDS: Admixture · Anguilla $\cdot$ Diel vertical migration $\cdot$ Satellite telemetry $\cdot$ Spawning Resale or republication not permitted without written consent of the publisher

\section{INTRODUCTION}

Both tropical and temperate eel species of the genus Anguilla live most of their lives in freshwater or estuaries before they migrate to offshore marine spawning areas. Their leaf-shaped larvae (leptocephali) drift with currents to their freshwater or coastal habitats. Therefore, they are vulnerable to human influences during their continental as well as oceanic reproductive stages, and understanding their 
complete life histories is essential for developing conservation efforts (Righton et al. 2012). The declining stocks of economically important temperate eel species, such as European A. anguilla, American A. rostrata or Japanese A. japonica eels, are raising concerns over a potential increase in commercial harvesting of tropical species that are being sought as new sources of eels. The recent listing of $A$. anguilla and A. japonica as 'Critically Endangered' (www.iucnredlist.org) may now intensify the demand for glass eels from undisturbed tropical populations (Arai 2014, Pickering 2014).

Four species of anguillid eels are present in the western South Pacific (WSP, Aoyama 2009): giant mottled eel $A$. marmorata, Polynesian long-finned eel $A$. megastoma, Australian long-finned eel $A$. reinhardtii and Polynesian short-finned eel $A$. obscura. Their freshwater distributions overlap in the archipelagos of Vanuatu and New Caledonia (Fig. 1; Ege 1939, Keith et al. 2011). However, little is known about their life histories (Jellyman 2003, Aoyama 2009, Tsukamoto 2009, Righton et al. 2012). One important first step is to locate their oceanic spawning areas and evaluate their population structures (Watanabe et al. 2011, Pickering 2014).

There may be 4 spawning populations of $A$. marmorata in the Pacific (North Pacific, Micronesia and 2 in the South Pacific), 2 of A. megastoma (eastern and western South Pacific) and single panmictic populations of $A$. reinhardtii and A. obscura based on their number of vertebrae (Ege 1939, Watanabe et al. $2008,2011)$. Molecular genetic data also suggest the existence of 3 or 4 populations of A. marmorata (Ishikawa et al. 2004, Minegishi et al. 2008, Gagnaire et al. 2011). Except for the North Pacific population of the latter species spawning in the North Equatorial Current (Chow et al. 2009, Kuroki et al. 2009, Tsukamoto et al. 2011), the other spawning areas are not known. Based on the distribution of a few leptocephali, they have been postulated to likely be somewhere within the South Equatorial Current (SEC; Aoyama 2009).

Studying the marine migration behaviour of eels may guide researchers to their spawning areas and provide evidence for the oceanographic seamarks the eels used to find them. All studied temperate (Jellyman \& Tsukamoto 2002, 2005, 2010, Aarestrup et al. 2009, Manabe et al. 2011) and tropical eels (Schabetsberger et al. 2013) make distinct diel vertical migrations, mostly swimming in the lower epipelagic zone $(\sim 150-250 \mathrm{~m})$ during the night and descending quickly to the deep mesopelagic zone ( 600-800 m) after sunrise, while remaining there during the day.

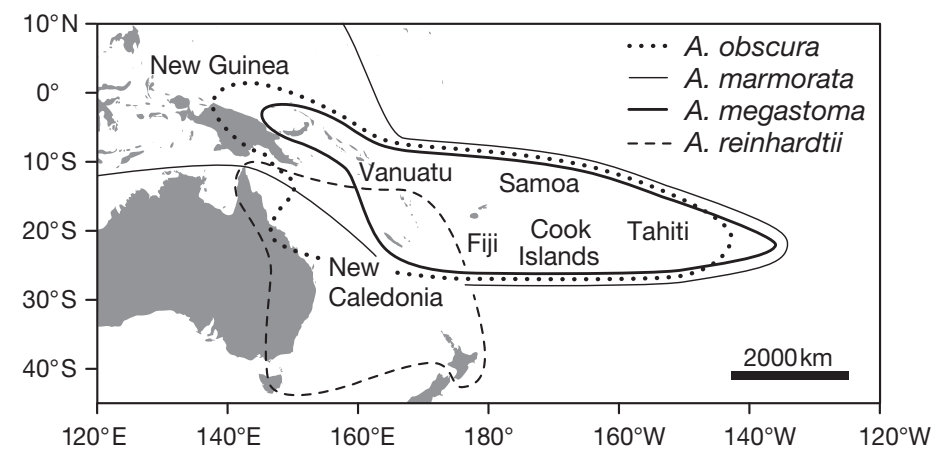

Fig. 1. Species ranges of the 4 tropical Pacific eels Anguilla spp. occurring in the Archipelago of Vanuatu. Range area of A. marmorata extends north of the equator and westward into the Indian Ocean

The descent into deep water may reduce predation from sharks (Manabe et al. 2011, Béguer-Pon et al. 2012), swordfish (Dewar et al. 2011), whales or other fish predators (Wahlberg et al. 2014), but final proof is lacking except for whales. It has also been hypothesized that eels descend into cold mesopelagic layers to slow gonadal development and remain in warmer shallow water for final maturation of the gonads (Jellyman \& Tsukamoto 2010), but information on the final approach to the spawning area is still lacking. To date, only a few spawning-condition A. japonica have ever been caught, and their ovaries were polycyclic, suggesting multiple spawning during consecutive new moon periods (Tsukamoto et al. 2011). Both eggs and newly hatched leptocephali were collected near the thermocline at a depth of around $160 \mathrm{~m}$ (Tsukamoto et al. 2011, Aoyama et al. 2014), possibly indicating spawning at the upper nighttime migration depth of eels.

For the few cases known, temperate eels seem to travel greater distances $(>2500 \mathrm{~km})$ than tropical eels ( $\leq 1000 \mathrm{~km}$; Aoyama et al. 2003) and seem to share spawning areas with other temperate or tropical species. In the Atlantic, A. anguilla and A. rostrata spawn in overlapping areas of the Sargasso Sea (Schmidt 1922, McCleave et al. 1987), and in the western North Pacific, A. japonica, A. marmorata and apparently A. luzonensis spawn in the North Equatorial Current (Chow et al. 2009, Tsukamoto et al. 2011, Kuroki et al. 2012). Sympatric and simultaneous spawning of European and American eels in the Sargasso Sea results in hybrids that are predominantly found in Iceland located between the recruitment areas of the 2 species (Albert et al. 2006). The hybrids are capable of migrating back to the spawning area and back-crossing with their parental species, suggesting that introgression is possible (Pujolar et al. 
2014). It remains unknown whether A. japonica and A. marmorata hybridise within their overlapping spawning areas or whether tropical eel species also share areas for reproduction. Under laboratory conditions, hybrid embryos of $A$. australis $\times A$. anguilla (Burgerhout et al. 2011), A. japonica $\times$ A. anguilla (Okamura et al. 2004) and A. australis $\times$ A. dieffenbachii (Lokman \& Young 2000) have been produced, proving the absence of a fertilization barrier between shortfinned and longfinned eels and distantly related species.

During our 2012 tagging experiments (Schabetsberger et al. 2013), a satellite tag on an A. marmorata released near the island of Gaua in Vanuatu surfaced $870 \mathrm{~km}$ northeast of the release area and approximately $300 \mathrm{~km}$ northwest of 2 points where 4 small leptocephali of this species and $1 \mathrm{~A}$. megastoma leptocephalus had been captured previously (Kuroki et al. 2008). In this region, the eastward flow of the South Equatorial Counter Current (SECC, $\sim 5-10^{\circ} \mathrm{S}$ ) splits the westward flowing SEC $\left(\sim 0-5^{\circ} \mathrm{S}\right.$ and $10-18^{\circ}$ $\mathrm{S})$ and an area of low surface salinity is present (Delcroix et al. 1987, Delcroix \& Picaut 1998, Hénin et al. 1998, Roden 1998, Miller et al. 2006, 2009), likely creating salinity and temperature fronts, which have been found to be possible seamarks for spawning of temperate species of Atlantic (Kleckner \& McCleave 1988, Munk et al. 2010) and Pacific (Kimura \& Tsukamoto 2006, Tsukamoto et al. 2011, Aoyama et al. 2014) eels.

In this study, we returned to the island of Gaua, Vanuatu, and used genetic information to investigate the possibility of shared spawning areas between tropical eels as indicated by evidence for introgression among species. We combined samples collected in 2012 during a previous study (Schabetsberger et al. 2013) with further samples collected in 2013 and also used telemetric information (8 silver eels tagged with pop-up satellite transmitters in 2013; also considering data from 1 eel from 2012, see Schabetsberger et al. 2013) and oceanographic data (Argos floats, 2012 and 2013) in order to determine the possible spawning areas of A. marmorata and A. megastoma in the WSP. We found strong evidence for hybridisation between the 2 species, and document joint pop-up areas that coincide with a distinct salinity maximum at the border between the SEC and the SECC.

\section{MATERIALS AND METHODS}

\section{Eel capture and morphological measurements}

The transportation, maintenance, measurements and tagging of eels followed our previous field protocols (Schabetsberger et al. 2013). Briefly, silver eels from the large volcanic Letas Lake on Gaua Island can only reach the sea through the outflowing Mbe Solomul River by plummeting over the $120 \mathrm{~m}$ high Siri Falls. Between 22 March and 3 April 2013, a total of 18 eels were caught, and 8 silver eels were tagged (Table 1). Of these 18 eels, local fishermen caught 13 eels below the falls by snorkelling with handnets; 2 had been caught 4 wk prior to our arrival in small creeks that start flowing into the river during the rainy season (January to March), and 3 small eels ( $<1 \mathrm{~kg}$ body weight) were collected by electrofishing. For genetic analysis, we also used samples of 65 eels collected during 2012 (Schabetsberger et al. 2013, Individual 17 missing). Eels from both years were each assigned identification numbers (Individuals 1-84). Eels that were equipped with a satellite tag received 'tagged eel numbers' (1-9; Table 1).

Table 1. Tagged eel number $(n=9)$, individual identification, species, total length (TL), body weight (BW), catch date, release date, pop-up day (surface) and position of tags put on 9 Anguilla marmorata, A. megastoma, and possibly admixed individuals from Gaua Island, Vanuatu. Eel 1 was tagged during a previous expedition (Schabetsberger et al. 2013)

\begin{tabular}{|c|c|c|c|c|c|c|c|c|}
\hline $\begin{array}{l}\text { Tagged } \\
\text { eel no. }\end{array}$ & $\begin{array}{c}\text { Individual } \\
\text { ID }\end{array}$ & Species & $\mathrm{TL}(\mathrm{cm})$ & BW (kg) & $\begin{array}{c}\text { Caught } \\
\text { (dd.mm.yy) }\end{array}$ & $\begin{array}{l}\text { Released } \\
\text { (dd.mm.yy) }\end{array}$ & $\begin{array}{c}\text { Surface } \\
\text { (dd.mm.yy) }\end{array}$ & Pop-up position \\
\hline 1 & 59 & A. marmorata & 129.6 & 5.7 & 31.01 .12 & 02.02 .12 & 02.05 .12 & $8.770^{\circ} \mathrm{S}, 173.016^{\circ} \mathrm{E}$ \\
\hline 2 & 70 & A. marmorata & 127.0 & 5.8 & 01.03 .13 & 24.03 .13 & Lost & \\
\hline 3 & 71 & A. marmorata & 139.5 & 6.2 & 01.03 .13 & 24.03 .13 & Lost & \\
\hline 4 & 72 & A. marmorata & 119.0 & 4.9 & 22.03 .13 & 24.03 .13 & 16.04 .13 & $14.331^{\circ} \mathrm{S}, 167.330^{\circ} \mathrm{E}$ \\
\hline 5 & 77 & Possibly admixed & 132.0 & 6.2 & 27.03 .13 & 30.03 .13 & 05.04 .13 & $13.781^{\circ} \mathrm{S}, 166.938^{\circ} \mathrm{E}$ \\
\hline 6 & 81 & A. marmorata & 121.5 & 4.9 & 02.04 .13 & 03.04 .13 & 06.09 .13 & $9.233^{\circ} \mathrm{S}, 170.462^{\circ} \mathrm{E}$ \\
\hline 7 & 82 & A. marmorata & 124.0 & 5.2 & 01.04 .13 & 03.04 .13 & 07.05 .13 & $12.590^{\circ} \mathrm{S}, 165.079^{\circ} \mathrm{E}$ \\
\hline 8 & 76 & A. megastoma & 118.0 & 3.8 & 30.03 .13 & 30.03 .13 & 28.06 .13 & $10.322^{\circ} \mathrm{S}, 174.614^{\circ} \mathrm{E}$ \\
\hline 9 & 83 & A. megastoma & 110.0 & 2.8 & 01.04 .13 & 03.04 .13 & 10.04 .13 & $13.421^{\circ} \mathrm{S}, 165.540^{\circ} \mathrm{E}$ \\
\hline
\end{tabular}


For examination, identification and tagging, eels were anaesthetised in a freshwater bath containing $40 \mathrm{\mu g} \mathrm{l}^{-1}$ metomidate (Marinil ${ }^{\mathrm{TM}}$, Wildlife Labs) until motionless. Total length, distance from lower jaw to the anus, dorsal fin and gill opening, as well as length of mouth and length of pectoral fin were measured to the nearest $\mathrm{mm}$. Horizontal and vertical eye diameter was measured to the nearest $0.1 \mathrm{~mm}$ with ruler callipers. Weight measurements were made to the nearest $10 \mathrm{~g}$. All eels were morphologically assigned to a species (Anguilla marmorata, A. megastoma or A. obscura) through inspection of the dentition of their upper jaw (following Ege 1939). Coloration of the body and the relative size of the eyes (Okamura et al. 2007) were used to classify silver eels. A small fin clip from the pectoral fin was removed and stored in $98 \%$ ethanol for genetic analysis.

\section{Genetic analyses}

Eighty-three eels caught in 2012 and 2013 were genetically characterized using a combination of mitochondrial and nuclear DNA sequencing and multi-locus microsatellite genotyping. Genomic DNA was extracted from fin clips stored in ethanol using a standard phenol-chloroform procedure (Sambrook et al. 1989) or a Qiagen DNeasy Blood and Tissue kit according to the manufacturer's recommendations.

To investigate mitochondrial sequence variation, we designed primers for a $527 \mathrm{bp}$ fragment spanning part of the cytochrome $b$ and control mtDNA regions based on available sequence information (MTF: GACTTTAACTTCCATCCTCAACTCCC, MTR: GGGAACTTGAAATAGGAGCCAAATGCCAG). $P C R$ reactions were carried out in a $20 \mu l$ reaction volume with GoTaq $\times 5$ reaction buffer $(1.5 \mathrm{mM}$ $\mathrm{MgCl}_{2}$ in $\times 1$ concentration), $200 \mu \mathrm{M}$ of each deoxyribonucleotide triphosphate (dNTP; Bioline), $0.2 \mu \mathrm{M}$ of each primer (MWG-Biotech) and 2.5 U GoTaq polymerase (Promega). An amplification profile of $5 \mathrm{~min}$ at $94^{\circ} \mathrm{C}$ for 1 cycle, followed by 35 cycles consisting of $30 \mathrm{~s}$ at $94^{\circ} \mathrm{C}, 30 \mathrm{~s}$ at $58^{\circ} \mathrm{C}$ and $30 \mathrm{~s}$ at $72^{\circ} \mathrm{C}$ was used.

To identify nuclear markers with the particular aim to differentiate between the study species, speciesrelevant sequences deposited at the National Center for Biotechnology Information (NCBI) were compared and primers were designed for 4 regions of interest. Sequencing identified 2 potentially diagnostic single nucleotide polymorphisms (SNPs) in one 268 bp region (GTH2bF: TCAATCATCTTACATCTGCAGC, GTH2bR: TAACCTTATTCTGTCAAGTGCG). PCR reactions were carried out in a $20 \mu \mathrm{l}$ reac- tion volume with the following constituents: $10 \mathrm{ng}$ genomic DNA, $1 \mu$ l GoTaq $\times 5$ reaction buffer (1.5 $\mathrm{mM} \mathrm{MgCl}_{2}$ in $\times 1$ concentration), $1 \mu \mathrm{M}$ of each primer, $0.25 \mathrm{mM}$ of each dNTP and $1 \mathrm{U}$ GoTaq DNA Taq polymerase. The PCR profile was as follows: $3 \mathrm{~min}$ at $94^{\circ} \mathrm{C}$, then 35 cycles of $94^{\circ} \mathrm{C}$ for $40 \mathrm{~s}, 52^{\circ} \mathrm{C}$ for $40 \mathrm{~s}, 72^{\circ} \mathrm{C}$ for $40 \mathrm{~s}$, and a final extension of $72^{\circ} \mathrm{C}$ for $4 \mathrm{~min}$.

Amplified PCR products of mitochondrial and nuclear genes were cleaned using a standard ethanol/ salt precipitation method and commercially sequenced (Source Bioscience). Sequences were examined using MEGA 5.01 (Tamura et al. 2013). For the mtDNA region, comparison with sequences in the NCBI nucleotide database and phylogenetic analysis using standard settings for a maximum likelihood tree was also used to match sequences with species. Phased haplotypes were estimated for GTH2b using Bayesian methods in PHASE (Stephens \& Donnelly 2003). Gametic phases with posterior probabilities equal to or higher than 0.7 were considered resolved (Harrigan et al. 2008). Indications of past recombination were examined using a PHI Test (Bruen et al. 2006) in SPLITSTREE 4 (Huson \& Bryant 2006). No significant signals of recombination were detected, and the full non-recombining sequence was used. Haplotype (hd) and nucleotide $(\pi)$ diversities, and number of haplotypes $(h)$ and segregating sites $(S)$ per marker and species were estimated using DnaSP 5.10.01 (Librado \& Rozas 2009). Pairwise $F_{\mathrm{ST}}$ per locus was estimated to evaluate the degree of genetic differentiation among the 3 main Anguilla species with 10000 permutations in ARLEQUIN 3.11 (Excoffier et al. 2005). Median joining networks were used to investigate genealogical relationships between haplotypes per gene with NETWORK 4.6.1.1 (Bandelt et al. 1999). Additionally, maximum-likelihood (ML) analyses of each gene were performed on PHYML 3.0 (Guindon et al. 2010) for 1000 replications, using the TN93 and TN93+I+G models for the GTH2b and control region (CR), respectively, as they best fitted the data based on Akaike's information criterion (AIC) using MODELTEST 3.7 (Posada \& Crandall 1998).

For an analysis of 6 nuclear microsatellite loci, the following previously published PCR primers were used: Aj-TR37 (Ishikawa et al. 2001), AangCT77 (Wielgoss et al. 2008), AM12, AM23, AM49 and AM54 (Xiao-Ling et al. 2009). PCR reactions were carried out as described in the aforementioned papers. PCR primers were labelled with HEX and FAM fluorescent dyes, and products were separated in an ABI3130 Genetic Analyser (Applied Biosystems). Alleles were scored using GENEMAPPER 4.0 
(Applied Biosystems). Hardy-Weinberg equilibria (applying a Bonferroni-corrected significance threshold) were calculated using GENEPOP ON THE WEB (Rousset 2008) considering only individuals assigned a pure species status based on the above criteria. Mean allelic richness was calculated using the software FSTAT 2.9.3.2 (Goudet 2002). The partitioning of genetic variation was addressed using the Bayesian clustering approach implemented in the software STRUCTURE 2.3.4 (Pritchard et al. 2000, Falush et al. 2003), considering all individuals including possibly admixed individuals. Given that 3 species were analysed, a $K=3$ using the correlated frequency model was assumed (1 000000 runs after 100000 burn-ins). The results were visualised using the triangle plot option implemented in STRUCTURE. To compute the Bayesian posterior probability of admixed individuals belonging to each parental and distinct hybrid class $(F 1, F 2$ and backcrosses between $F 1$ and parental species) NEWHYBRIDS 1.1 (Anderson \& Thompson 2002) was used, employing the Jeffreyslike prior and considering 100000 runs after 100000 burn-ins. We restricted this analysis to $A$. marmorata and A. megastoma due to a low sample size for A. obscura.

\section{Tagging}

The tagging and release procedures conducted in 2013 were identical to the previous year. One A. marmorata that migrated with its tag to $870 \mathrm{~km}$ northwest of Gaua (Schabetsberger et al. 2013) is also included in this study for ease of comparison (Table 1, Tagged Eel 1). Eight captured eels showed signs of silvering (median eye index: 14.0, range 9.8-16.2) and were transported within $2 \mathrm{~h}$ to a $2 \mathrm{~m}$ long and $1 \mathrm{~m}$ wide keep-net (mesh size $\sim 2 \mathrm{~mm}$ ) submerged in the Mbe Solomul River about $100 \mathrm{~m}$ from its mouth. Six eels were uninjured, while Eel 4 bore a healing wound ( $2 \mathrm{~cm}$ diameter) on its back from a metal hook, and Eel 5 had a fresh, similar sized hooking mark on its tail.

After being held for 5 to $72 \mathrm{~h}$ in the keep-net, the eels were removed individually and anaesthetised as described above. Pop-up satellite transmitters (PSATs, X-tags, Microwave Telemetry) were attached externally (Schabetsberger et al. 2013). The tag is $12 \mathrm{~cm}$ long (excluding antenna), $32 \mathrm{~mm}$ wide and weighs $42 \mathrm{~g}$ in air. Eels recovered from anaesthesia within less than $5 \mathrm{~min}$. Subsequently, the eels were placed into 2 aluminium boxes filled with fresh water (frequently changed to ensure high oxygen concentrations) and transported 3.6 to $3.8 \mathrm{~km}$ offshore east of Gaua Island. Saltwater was gradually added during the $\sim 30 \mathrm{~min}$ passage. Eels were tagged and released on different days in subsets of 3,2 and 3 fish. Sensors in the tag collected and archived data on pressure (depth) and water temperature. The tags were programmed to detach after $5 \mathrm{mo}$, and once the tags were released and ascended to the surface, they transmitted data to ARGOS satellites. A fail-safe release mechanism ensured that the tag surfaced and transmitted data in case the eel stopped moving (triggered by a depth reading $>2100 \mathrm{~m}$, or $3 \mathrm{~d}$ of equal depth).

\section{Oceanographic conditions}

To examine the oceanographic conditions in the areas where the tags popped up during both years, an analysis was carried out using interpolated temperature and salinity fields gridded to a spatial resolution of $1^{\circ}$, with a temporal resolution of $1 \mathrm{mo}$, and with 25 vertical levels from the surface to 2000 dbars. The original data used in the interpolation were obtained from Argo floats (www.jamstec.go.jp/ ARGO/argo_web/MapQ/Mapdataset_e.html) and moored ocean buoys (TRITON, www.pmel.noaa.gov /tao/). Zonal geostrophic currents were also calculated with respect to a reference depth of $2000 \mathrm{~m}$. Bathymetry data were gathered from the ETOPO 1minute dataset (www.ngdc.noaa.gov/mgg/global/ global.html).

\section{RESULTS}

\section{Species identification}

Based on visual inspection of the upper jaw dentition, we assigned 32 individuals to Anguilla marmorata $(31-140 \mathrm{~cm}), 45$ individuals to $A$. megastoma $(50-123 \mathrm{~cm})$ and 7 individuals to A. obscura (62-129 $\mathrm{cm})$. Genetic data were obtained for 83 of these 84 individuals. Combining morphological evidence with sequence data (mtDNA and nuclear DNA); however, 13 individuals could not be unambiguously assigned to a single species. In total, 3 A. marmorata and 10 A. megastoma possessed an mtDNA haplotype assigned to a species other than that indicated by their morphology (Table 2, Fig. 2A). While the overall nuclear GTH2b haplotype network was less informative overall (Fig. 2B), 8 individuals also possessed a heterozygote genotype at 2 otherwise species- 
Table 2. Genetic classification of 13 possibly admixed individual eels of Anguilla spp. The mtDNA haplotype is based on a $527 \mathrm{bp}$ long control region sequence; the nuclear haplotypes are based on a $268 \mathrm{bp}$ sequence of the GTH2b gene, including 2 polymorphic, species-diagnostic single nucleotide polymorphisms (SNPs) for which Y denotes C or T. Numbers 55 (labelled as Eel 3 by Schabetsberger et al. 2013) and 77 (Tagged Eel 5, Table 1) were tagged with satellite tags. - denotes missing data

\begin{tabular}{|c|c|c|c|c|c|c|}
\hline $\begin{array}{l}\text { Individual } \\
\text { ID }\end{array}$ & $\begin{array}{c}\text { Morphological } \\
\text { species designation }\end{array}$ & $\begin{array}{c}\text { mtDNA } \\
\text { haplotype }\end{array}$ & $\begin{array}{l}\text { Length } \\
\text { (cm) }\end{array}$ & $\begin{array}{l}\text { Weight } \\
(\mathrm{kg})\end{array}$ & $\begin{array}{l}\text { Nuclear } \\
\text { SNP } 86\end{array}$ & $\begin{array}{l}\text { Nuclear } \\
\text { SNP } 169\end{array}$ \\
\hline 12 & A. megastoma & A. marmorata & 131 & 5.5 & $\mathrm{Y}$ & $\mathrm{Y}$ \\
\hline 18 & A. megastoma & - & 116 & 4.9 & $\mathrm{Y}$ & $\mathrm{Y}$ \\
\hline 19 & A. megastoma & A. marmorata & 103 & 3.2 & $\mathrm{Y}$ & $\mathrm{Y}$ \\
\hline 23 & A. megastoma & A. megastoma & 97 & 2.6 & $\mathrm{C}$ & $\mathrm{Y}$ \\
\hline 24 & A. megastoma & A. marmorata & 88 & 1.9 & $\mathrm{~T}$ & $\mathrm{C}$ \\
\hline 33 & A. marmorata & A. megastoma & 105 & - & $\mathrm{C}$ & $\mathrm{T}$ \\
\hline 37 & A. megastoma & A. marmorata & 115 & - & $\mathrm{Y}$ & $\mathrm{Y}$ \\
\hline 40 & A. megastoma & A. marmorata & 108 & 2.6 & $\mathrm{Y}$ & $\mathrm{Y}$ \\
\hline 44 & A. marmorata & A. megastoma & 142 & 5.6 & $\mathrm{Y}$ & $\mathrm{Y}$ \\
\hline 49 & A. megastoma & A. obscura & 122 & 5.0 & - & - \\
\hline 55 & A. megastoma & A. marmorata & 117 & 4.9 & $\mathrm{Y}$ & $\mathrm{Y}$ \\
\hline 77 & A. marmorata & A. marmorata & 132 & 6.2 & $\mathrm{Y}$ & $\mathrm{Y}$ \\
\hline 87 & A. megastoma & A. marmorata & 80 & - & - & - \\
\hline
\end{tabular}

specific nuclear SNPs (C/T at base position 86, and T/C at base position 169; pure $A$. megastoma and $A$. obscura showed genotype $\mathrm{C}$ and $\mathrm{T}$, respectively, whereas A. marmorata had genotype $\mathrm{T}$ and $\mathrm{C}$, see Fig. S1 in the Supplement, at www.int-res.com/ articles/suppl/mXXXpXXX_supp.pdf), regardless of their overall position in the haplotype network. One individual (an A. marmorata) only showed this nuclear heterozygosity despite concordance between mtDNA and morphology, and 2 further individuals disagreed between mtDNA and morphology at homozygote nuclear genotypes. We classified these 13 individuals as possibly admixed (Table 2). This assertion is further corroborated with multi-locus microsatellite genotypes. NEWHYBRIDS revealed mean posterior values of 0.812 (A. marmorata) and 0.906 (A. megastoma) for pure species, with $83.7 \%$ of individuals having the highest probability of assignment to their morphospecies. All but 2 possibly introgressed individuals had the highest likelihood of assignment to a hybrid class (Table 3 ).

\section{Genetic population structure}

Overall, 70 sequences of $268 \mathrm{bp}$ and 80 sequences of $527 \mathrm{bp}$ for the GTH2b and CR genes were used, respectively. The remaining samples had to be dis-

Table 3. Assignment probability of putatively admixed individuals of Anguilla spp. to pure species and different hybrid classes ( $F 1$ and $F 2$, and their back-crosses to parental species) using NEWHYBRIDS, based on genotypes at 6 microsatellite loci

\begin{tabular}{|lcccccc|}
\hline Individual ID & Pure A. marmorata & Pure A. megastoma & $F 1$ & $F 2$ & F1/A. marmorata & F1/A. megastoma \\
\hline 12 & 0.000 & 0.002 & 0.251 & 0.580 & 0.121 & 0.047 \\
18 & 0.022 & 0.000 & 0.398 & 0.270 & 0.307 & 0.004 \\
19 & 0.000 & 0.000 & 0.337 & 0.494 & 0.159 & 0.010 \\
23 & 0.959 & 0.000 & 0.000 & 0.010 & 0.031 & 0.000 \\
24 & 0.625 & 0.000 & 0.000 & 0.178 & 0.194 & 0.000 \\
33 & 0.000 & 0.131 & 0.000 & 0.809 & 0.000 & 0.060 \\
37 & 0.000 & 0.000 & 0.847 & 0.096 & 0.050 & 0.007 \\
40 & 0.003 & 0.000 & 0.012 & 0.619 & 0.364 & 0.000 \\
44 & 0.000 & 0.000 & 0.912 & 0.059 & 0.021 & 0.007 \\
49 & 0.000 & 0.096 & 0.000 & 0.016 & 0.000 & 0.027 \\
77 & 0.000 & 0.000 & 0.757 & 0.158 & 0.073 & 0.012 \\
87 & 0.011 & 0.000 & 0.028 & 0.465 & 0.496 & 0.000 \\
\end{tabular}


(A)
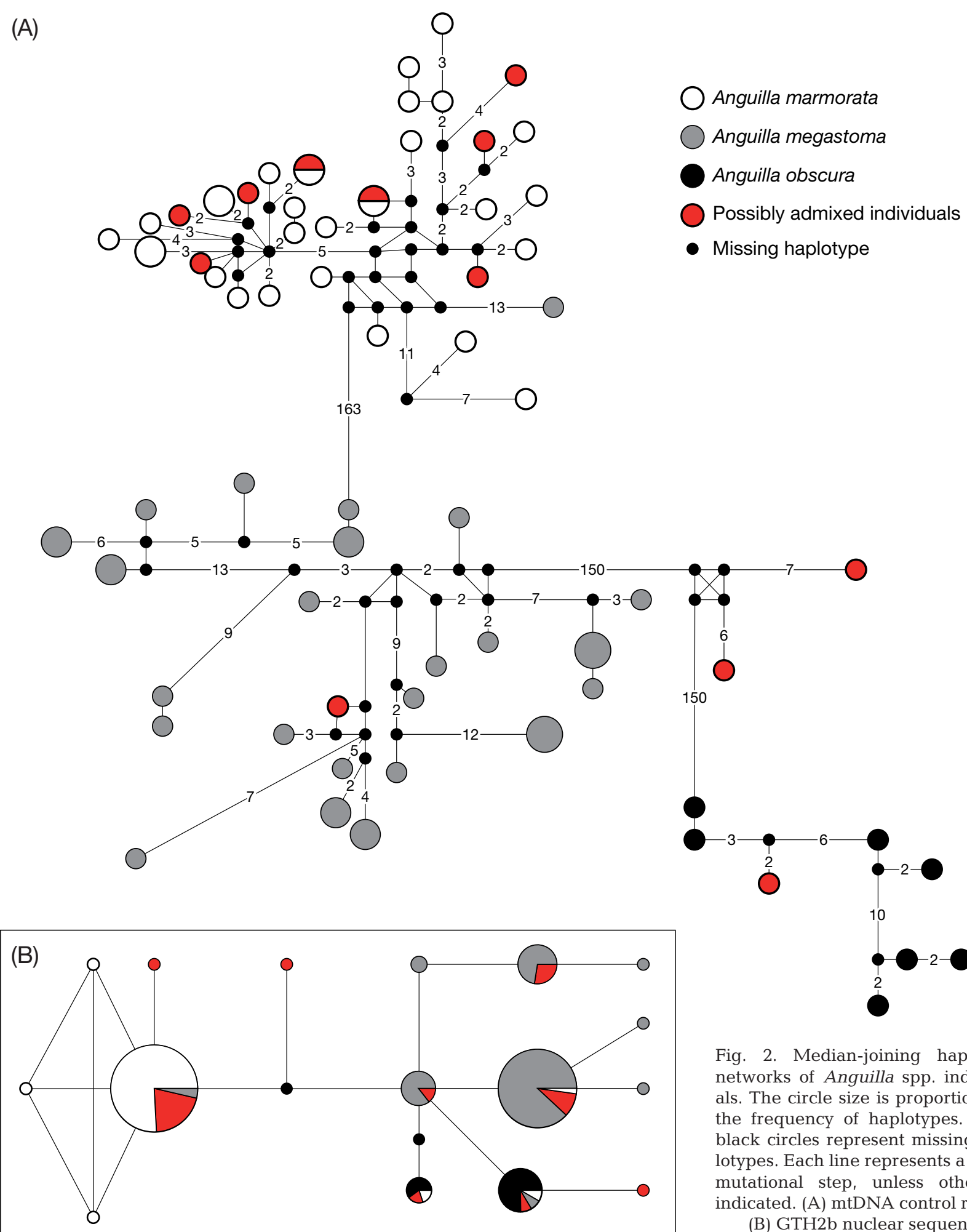

Fig. 2. Median-joining haplotype networks of Anguilla spp. individuals. The circle size is proportional to the frequency of haplotypes. Small black circles represent missing haplotypes. Each line represents a single mutational step, unless otherwise indicated. (A) mtDNA control region,

(B) GTH2b nuclear sequence

carded due to PCR failure or insufficient quality of sequences. All gametic phases were resolved for the nuclear gene with no significant indication of recombination. Genetic diversity was overall high, and higher in the mitochondrial than the nuclear locus for all 3 species. At the nuclear level, A. megastoma possessed a higher genetic variation than $A$. obscura and A. marmorata, while A. marmorata and A. megastoma had a higher level of variation at the mitochondrial level (Table 4). All 3 species were significantly 
Table 4. Summary statistics for the mtDNA control region (CR, $527 \mathrm{bp})$ and nuclear GTH2b partial gene sequences (268 bp) of 3 Anguilla species (putative hybrid individuals were excluded from this analysis). n: number of individual haplotypes ( 2 haplotypes per individual eel for GTH2b); hd: haplotype diversity; $\pi$ : nucleotide diversity; $h$ : number of different haplotypes; $S$ : number of polymorphic sites. Standard deviations are in brackets

\begin{tabular}{|lrccrc|}
\hline & $\mathrm{n}$ & hd & $\pi$ & $h$ & $S$ \\
\hline CR & & & & & \\
A. megastoma & 32 & $0.976( \pm 0.013)$ & $0.048( \pm 0.001)$ & 22 & 99 \\
A. marmorata & 28 & $0.995( \pm 0.011)$ & $0.030( \pm 0.002)$ & 26 & 81 \\
A. obscura & 7 & $1.000( \pm 0.076)$ & $0.029( \pm 0.004)$ & 7 & 31 \\
GTH2b & & & & & \\
A. megastoma & 56 & $0.539( \pm 0.052)$ & $0.00423( \pm 0.00068)$ & 7 & 6 \\
A. marmorata & 48 & $0.199( \pm 0.077)$ & $0.00092( \pm 0.00039)$ & 6 & 3 \\
A. obscura & 14 & $0.440( \pm 0.112)$ & $0.00492( \pm 0.00125)$ & 2 & 3 \\
\hline
\end{tabular}

Table 5. Genetic variation at 6 microsatellite loci for each eel species $A n$ guilla spp. n: sample size; $H_{\mathrm{o}}$ : observed heterozygosity; $H_{\mathrm{e}}$ : expected heterozygosity; HWE: Hardy-Weinberg equilibrium. Individuals with possibly admixed genotypes (listed in Table 2) were excluded from the analysis

\begin{tabular}{|lrrccc|}
\hline Species & $\mathrm{n}$ & $\begin{array}{c}\text { Mean } \\
H_{\mathrm{o}}\end{array}$ & $\begin{array}{c}\text { Mean } \\
H_{\mathrm{e}}\end{array}$ & $\begin{array}{c}\text { Loci out } \\
\text { of HWE }\end{array}$ & $\begin{array}{c}\text { Mean } \\
\text { allelic richness }\end{array}$ \\
\hline A. marmorata & 28 & 0.78 & 0.79 & $A M 49$ & 6.62 \\
A. megastoma & 35 & 0.69 & 0.77 & - & 7.79 \\
A. obscura & 7 & 0.69 & 0.67 & - & 8.61 \\
\hline
\end{tabular}

roborated by the ML topologies (Fig. S2 in the Supplement).

The examined microsatellites were highly polymorphic, having between 4 and 38 alleles per locus and species ( 7 to 43 alleles across all species) and being largely in Hardy-Weinberg equilibrium within each species (Table 5). The 3 considered species were clearly genetically differentiated but also lacked speciesspecific common alleles (pairwise $F_{\text {st }}$ values: A. marmorata - A. megastoma 0.21, A. marmorata - A. obscura 0.20, A. megastoma - A. obscura 0.26). The analysis using STRUCTURE revealed 3 distinct clusters in accordance with species identification (Fig. 3), although the cluster for $A$. megastoma also included 2 A. marmorata, and the A. obscura cluster contained individuals of all 3 species. Seven possibly admixed individuals (together with about $10 \%$ of the putative pure individuals) were clearly not assigned to a cluster, while 4 possibly admixed individuals clustered with $A$. obscura, and 1 clustered with A. marmorata and A. megastoma each. differentiated from each other (pairwise differences, GTH2b: A. marmorata - A. megastoma 0.788, A. marmorata - A. obscura 0.934, A. megastoma - A. obscura 0.639, CR: A. marmorata - A. megastoma 0.936, A. marmorata - A. obscura 0.952, A. megastoma - A. obscura 0.927, all p < 0.001). The medianjoining network based on the mtDNA sequences presents 3 main groups separated from each other by a large number of haplotypes and largely representing the 3 study species. However, it also contains a further clearly separated cluster comprising only 2 individuals (Fig. 2A). All possibly admixed individuals are assigned to the A. marmorata mtDNA cluster except 1 individual assigned to each of the A. megastoma and $A$. obscura clusters and 2 further possibly admixed individuals form a separate group between A. megastoma and A. obscura. The median-joining network based on the nuclear GTH2b sequence was less clearly resolved, but still largely clustered the 3 species together (Fig. 2B). Only A. obscura specimens do not group with the main haplogroups of $A$. megastoma and A. marmorata, confirming that this species is rather distinct from the other 2 species. The possibly admixed individuals are evenly spread across the main groups. Such patterns were also cor-

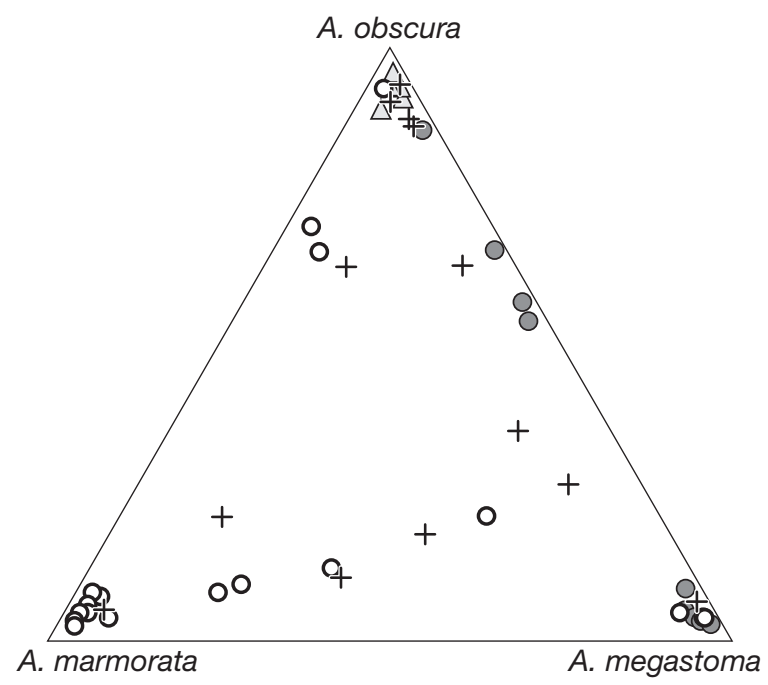

Fig. 3. STRUCTURE analysis of 3 Anguilla spp. based on 6 polymorphic microsatellite loci, using the triangle plot implemented in the software. The algorithm was run assuming 3 clusters $(K=3)$ to represent 3 species under consideration. Irrespective of their assignment to these 3 clusters, all considered individuals were divided into 4 groups using the population identifiers option. Open circles: A. marmorata, gray circles: A. megastoma, triangles: A. obscura, +: possibly admixed individuals 


\section{Oceanic migration behaviour}

Tags surfacing within the Archipelago of Vanuatu. Two tags never started transmission for unknown reasons (Tagged Eels 2 and 3). Those tags providing data (Eels 4 to 9, see below), surfaced prematurely and started transmitting $3 \mathrm{~d}$ after pop-up 10 to $320 \mathrm{~km}$ west of Gaua (Table 1). All eels exhibited pronounced diel vertical migrations between shallow nighttime (19:00-04:00 h) and deep daytime (06:00-17:00 h) depths during crepuscular periods. Ascents and descents were completed within 2 to $3 \mathrm{~h}$. The deepest dives were down to $877 \mathrm{~m}$, corresponding to $4.5^{\circ} \mathrm{C}$. Average migration speeds of eels moving offshore (Eels 5 and 7 ) were $\sim 10 \mathrm{~km} \mathrm{~d}^{-1}$.

A. marmorata, Eel 4 (Table 1). Over the first $11 \mathrm{~d}$ after release, this eel gradually increased its daily median lower migration depths from 226 to $495 \mathrm{~m}$, corresponding to a temperature decrease from 17.9 to $7.0^{\circ} \mathrm{C}$, while its upper nighttime migration depths remained around $161 \mathrm{~m}$ and at a temperature of $21.7^{\circ} \mathrm{C}$. It then abruptly increased the amplitude of its diel movements to be from median depths of 769 to $167 \mathrm{~m}$ for another $13 \mathrm{~d}$ before the tag started transmitting only $10 \mathrm{~km}$ west of Gaua, showing that the fish had not commenced any long-distance migration. Median daytime and nighttime temperatures experienced in the latter period were 21.7 and $5.2^{\circ} \mathrm{C}$, respectively.

Possibly admixed individual, Eel 5. Over a period of $6 \mathrm{~d}$, Eel 5 commenced its gradual descent by increasing minimum daytime depths from 447 to $597 \mathrm{~m}$, with temperature decreasing from 8.4 to $5.8^{\circ} \mathrm{C}$. Median nighttime depth was around $135 \mathrm{~m}$, corresponding to $23.4^{\circ} \mathrm{C}$. The tag surfaced early and started transmitting $75 \mathrm{~km}$ northwest of Gaua less than 1 wk after the eel was released.

A. marmorata, Eel 7. Over 23 d, this eel increased its daytime depths from 479 to $694 \mathrm{~m}$ and nighttime depths from around 140 to $220 \mathrm{~m}$, corresponding to a temperature decrease from 7.3 to $5.2^{\circ} \mathrm{C}$ and from around 22.3 to $17.6^{\circ} \mathrm{C}$, respectively. For another $11 \mathrm{~d}$, the daytime depths remained similar at about $690 \mathrm{~m}$ and at a temperature of $5.2^{\circ} \mathrm{C}$, while nighttime depths decreased again to $135 \mathrm{~m}$, corresponding to $22.7^{\circ} \mathrm{C}$. After a short descent to $812 \mathrm{~m}$, the tag surfaced early after $35 \mathrm{~d}$ and started transmitting $320 \mathrm{~km}$ northwest of Gaua.

A. megastoma, Eel 9. This eel exhibited some irregular movements between the surface and about $250 \mathrm{~m}$ depths, spending most time around $70 \mathrm{~m}$ before the tag popped up 1 wk after release. For unknown reasons, it started transmitting $20 \mathrm{~d}$ after pop-up $225 \mathrm{~km}$ northwest of Gaua.

\section{Tags surfacing outside the Archipelago of Vanuatu}

Tags on 2 A. marmorata and 1 A. megastoma surfaced between 634 and $874 \mathrm{~km}$ northeast from the point of release (Table 1, Fig. 4). The different attachment lengths indicate that the eels can reach the region (approximately $460 \times 175 \mathrm{~km}$ ) within 3 mo or earlier and that they might remain there for another 1 to 2 mo. Average long-distance migration speeds for the 3 eels were $\sim 10 \mathrm{~km} \mathrm{~d}^{-1}$.

A. marmorata, Eel 1. The eel tagged during our previous study exhibited a distinct diel vertical migration behaviour that was adjusted at night to the lunar cycle as described in detail by Schabetsberger et al. (2013). Briefly, it ascended from a median depth

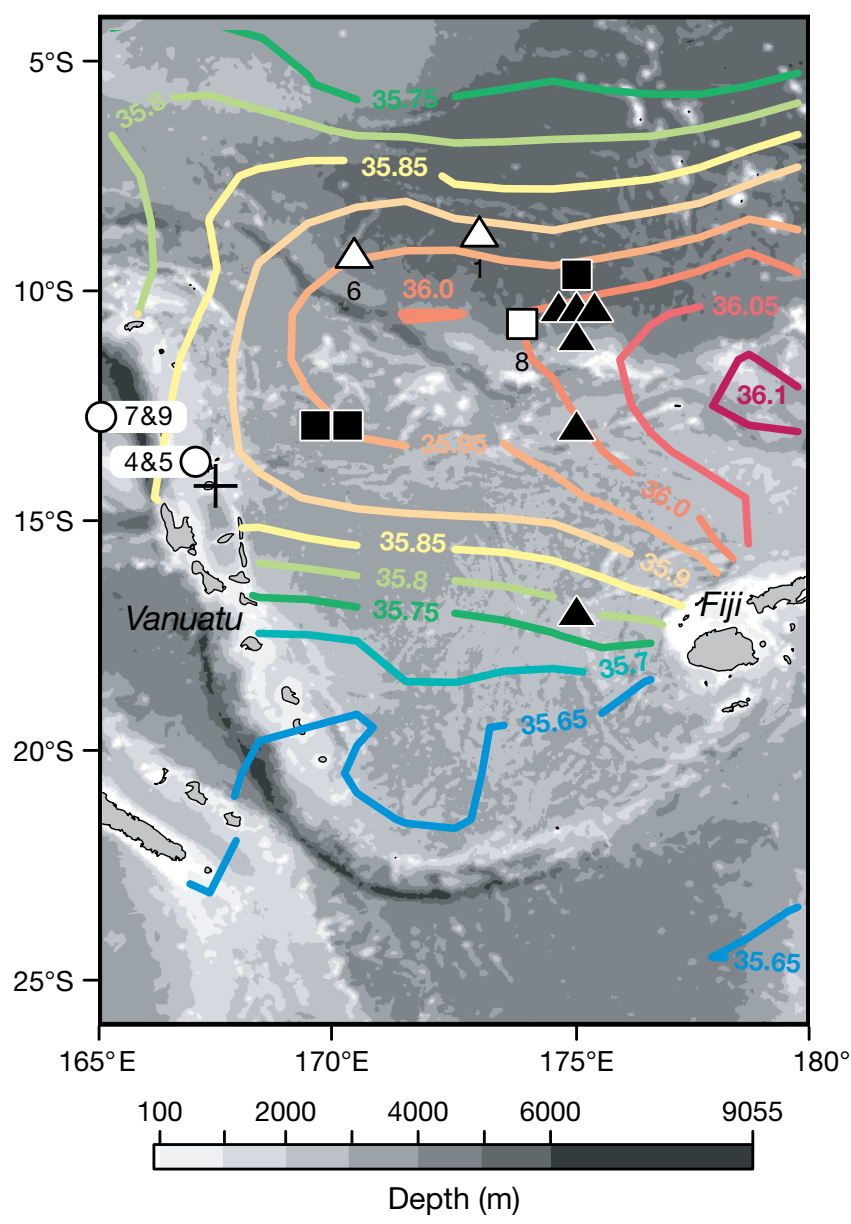

Fig. 4. Bathymetry of the study region, with isohalines at $150 \mathrm{~m}$ depth during May 2012. Release position of tagged silver eels Anguilla spp. (cross), pop-up locations of tags (white triangles and squares, Eels 1, 6, 8) and distribution of leptocephali (black symbols, Kuroki et al. 2008) are shown (triangles: A. marmorata; squares: A. megastoma). White circles indicate pop-up positions of tags put on A. marmorata (Eels 4 and 7), A. megastoma (Eel 9) and 1 hybrid (Eel 5) and surfacing prematurely within the Archipelago of Vanuatu 
(A) Anguilla marmorata Eel 6

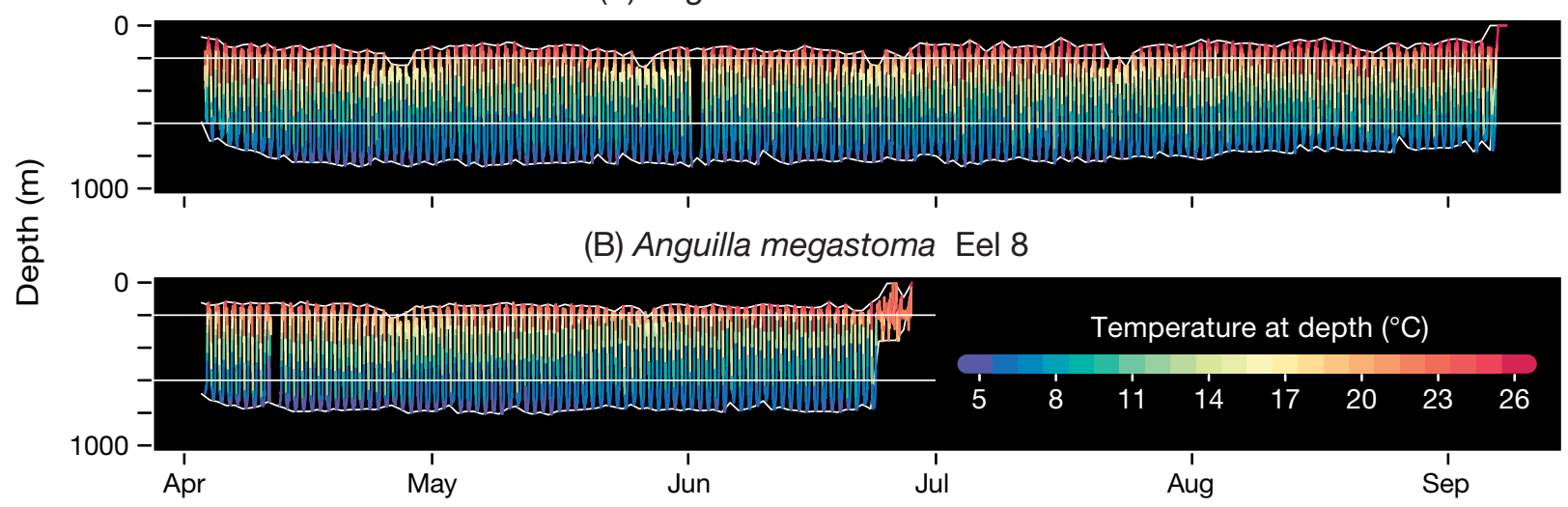

Fig. 5. Vertical migrations of (A) Anguilla marmorata (Eel 6) and (B) A. megastoma (Eel 8) with the temperatures experienced by the eels shown on the colour bar. White lines indicate 200 and $600 \mathrm{~m}$ depth for ease of comparison

of $631 \mathrm{~m}$ during the day to $170-230 \mathrm{~m}$ during the night. Concurrently, temperatures oscillated between 6.0 and $23.0^{\circ} \mathrm{C}$. The tag surfaced exactly after the programmed $3 \mathrm{mo}, 870 \mathrm{~km}$ northeast from the point of release (Fig. 4).

A. marmorata, Eel 6. The tag remained on Eel 6 for the full pre-programmed 5 mo (Fig. 5A). During the first $3 \mathrm{wk}$, its daytime depths increased from around 610 to $818 \mathrm{~m}$, with a concurrent decrease in temperature from 6.6 to $5.3^{\circ} \mathrm{C}$. The minimum temperature encountered was $5.0^{\circ} \mathrm{C}$. From the beginning, the eel apparently adjusted its upper nighttime migration depths to moonlight or lunar phase, descending from around $160 \mathrm{~m}$ during new moon to $300 \mathrm{~m}$ during full moon nights (Fig. 6A). After the first $3 \mathrm{wk}$, median daytime and nighttime depths were 769 and $194 \mathrm{~m}$, corresponding to 5.8 and $21.9^{\circ} \mathrm{C}$, respectively. However, a weak trend towards shallower depths was observed, especially after the fourth full moon period after release. Just before the tag popped up, the median day- and nighttime depths had decreased to 672 and $145 \mathrm{~m}$, corresponding to 6.6 and $24.4^{\circ} \mathrm{C}$, respectively. The shallowest depth the eel ever went to was $75 \mathrm{~m}$ during a new moon period $3 \mathrm{wk}$ prior to pop-up. The tag surfaced as scheduled and started transmitting approximately $634 \mathrm{~km}$ northeast from the point of release (Fig. 4).

A. megastoma, Eel 8. During the first $16 \mathrm{~d}$, this eel gradually increased its daytime migration depths from 570 to $759 \mathrm{~m}$, corresponding to a decrease in

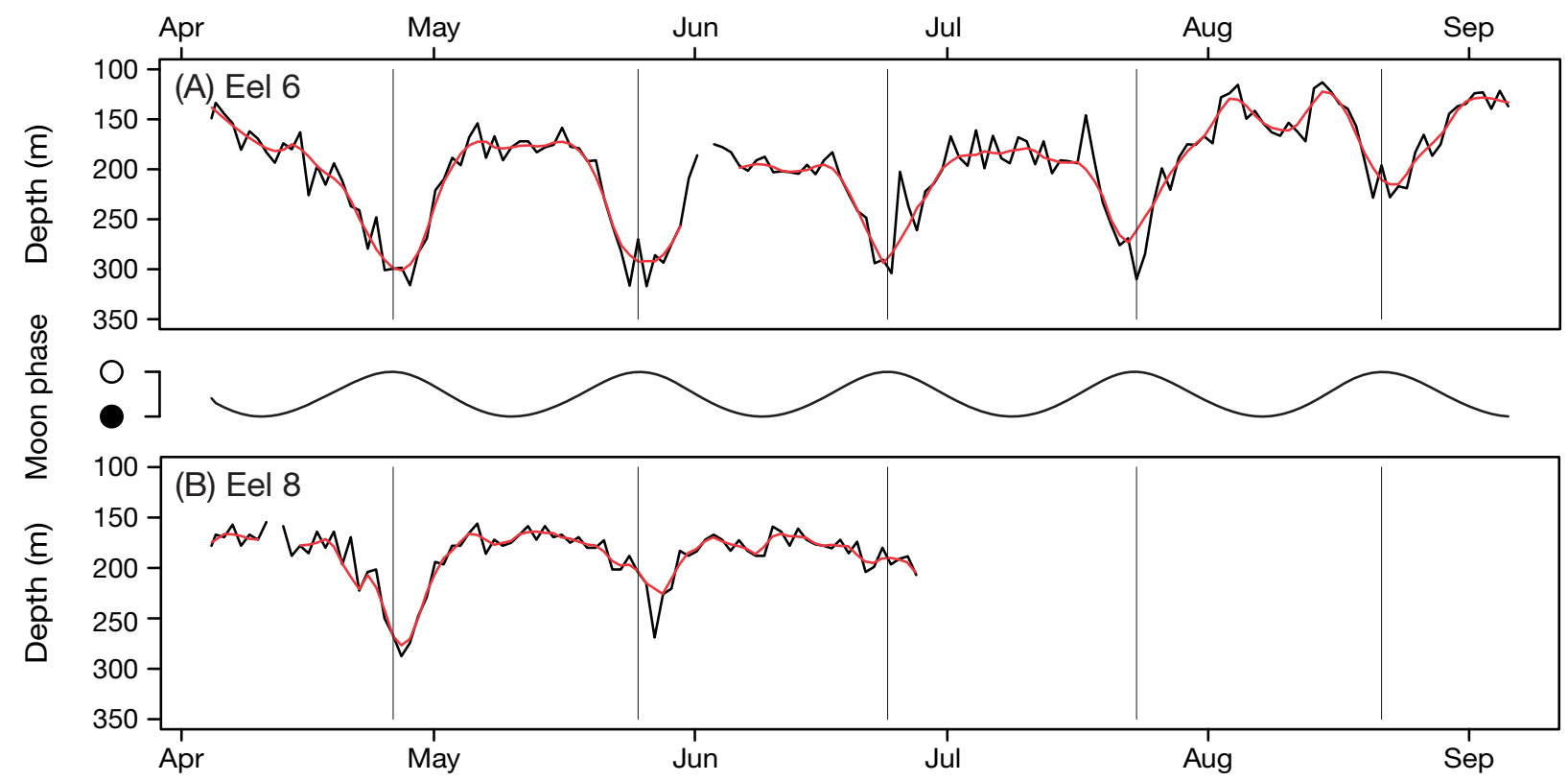

Fig. 6. Nighttime upper migration depths (black line: median, red line: spline curve) of (A) Anguilla marmorata (Eel 6) and (B) A. megastoma (Eel 8) in relation to moon phase (white circle: full moon; black circle: new moon) 
temperature from 6.6 to $5.0^{\circ} \mathrm{C}$ (Fig. 5B). Similar to $A$. marmorata, a clear effect of moon phase on the upper migration depth was confirmed for the first time for this species (Fig. 6B). After about 2 wk, Eel 8 migrated between a daytime median depth of $748 \mathrm{~m}$ to a nighttime median depth of $183 \mathrm{~m}$, corresponding to temperatures of 5.7 and $22.0^{\circ} \mathrm{C}$. One week prior to pop-up in late June, the tag suddenly recorded shallower depths around $200 \mathrm{~m}$ and occasional ascents to the surface, with corresponding median tempera- tures around $22.5^{\circ} \mathrm{C}$. The tag surfaced 2 mo early and started transmitting $874 \mathrm{~km}$ northeast from the point of release (Fig. 4).

\section{Oceanographic conditions}

Meridional sections of salinity along the 3 pop-up locations showed that there was a high salinity core between 100 and $200 \mathrm{~m}$ in the pop-up region (Fig. $7 \mathrm{~A}-\mathrm{C})$. The thermocline was found at the upper

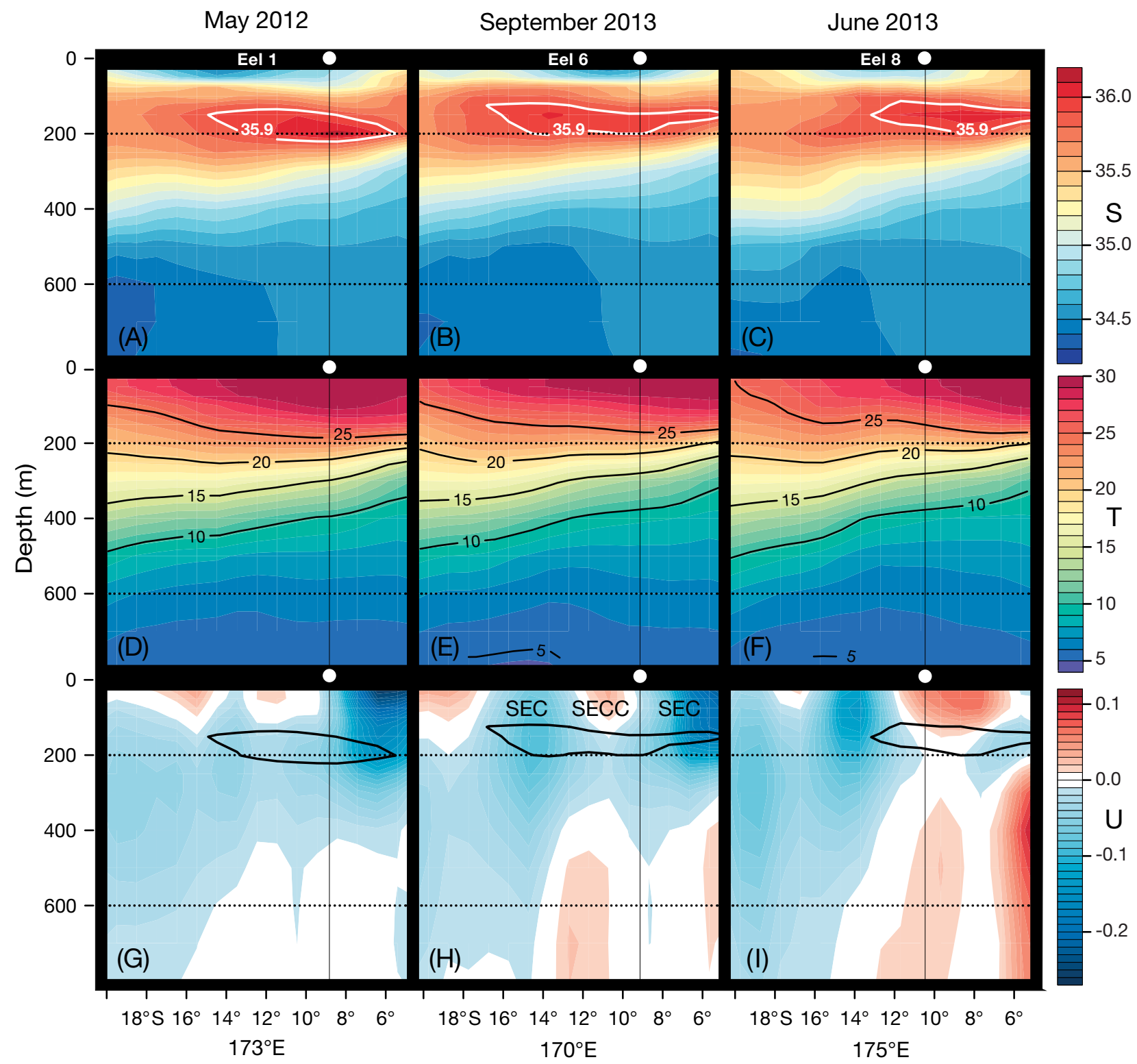

Fig. 7. Monthly mean meridional sections between 0 and $800 \mathrm{~m}$ depths of $(\mathrm{A}-\mathrm{C})$ salinity $(\mathrm{S}),(\mathrm{D}-\mathrm{F})$ temperature $(\mathrm{T})$ and $(\mathrm{G}-\mathrm{I})$ zonal geostrophic velocity $\left(U, \mathrm{~m} \mathrm{~s}^{-1}\right.$; red: eastward currents; blue: westwards currents; black line: contour of salinity equal to 35.9) centred on the longitude of the pop-up locations of tags on 2 Anguilla marmorata (A,D,G: Eel 1, May 2012, 173 E; B,E,H: Eel 6, September 2013, 170 E) and 1 A. megastoma (C,F,I: June $2013175^{\circ}$ E,). The 2-core South Equatorial Current (SEC) and the South Equatorial Counter Current (SECC) are indicated in (H). White circles on top of panels represent pop-up latitudes. Black dotted lines indicate 200 and $600 \mathrm{~m}$ depths 
migration depths of eels (Fig. 7D-F). The pop-up region is located at the dynamic northern border between the SEC and the SECC (Fig. 7G,H). The latter current was weak or almost absent during the months when the tags surfaced. Between May and September and 300 to $700 \mathrm{~m}$ below the pop-up location, a weak eastward propagating current may have been present at depths >300-400 m. The salinity maximum occurred below the SECC and within the westward propagating SEC. The area where the tags surfaced were all north of the edge of a deep bathymetric basin where bottom depths rapidly increase from about $3500 \mathrm{~m}$ to more than $5000 \mathrm{~m}$. Fig. 4 shows the spatial extent of the high salinity core (at $150 \mathrm{~m}$ in May 2012) in relation to the pop-up locations.

\section{DISCUSSION}

\section{Genetic evidence for admixture and sympatric spawning}

Based on morphology and on several types of genetic markers, the present study provides evidence for admixture between Anguilla marmorata and A. megastoma. Overall, the study adds to the accumulating evidence from Atlantic eels that natural hybridisation between species occurs in the genus Anguilla (Albert et al. 2006, Pujolar et al. 2014, Wielgoss et al. 2014).

Apart from genetic admixture, the observed disconcordances between morphology, mitochondrial, and nuclear DNA sequences could also be caused by wrong morphological species identification, as well as incomplete lineage sorting. Given the frequent occurrence of conflicting evidence between the 2 types of genetic markers, we can exclude that morphological identification alone accounts for the intermediate individuals. Incomplete lineage sorting can usually be distinguished from admixture and introgression by investigating the spatial distribution of haplotypes (e.g. Toews \& Brelsford 2012), which is, however, impossible for migrating eels with unknown spawning area delimitations. It nevertheless appears that hybridisation and introgression, resulting in individuals of admixed origin, is at least co-responsible for the observed patterns of genetic variation. Firstly, the majority of all individuals with disconcordant nuclear and mitochondrial species designations possessed a heterozygote genotype at otherwise fully diagnostic nuclear SNPs, irrespective of the entire GTH2b sequence (Table 2, Fig. S1 in the Supplement). This coincidence would be difficult to explain by assuming incomplete lineage sorting (mitochondrial and/or nuclear) alone. While the observed heterozygosities at these SNPs could also be based on within-species polymorphisms, only a single homozygote genotype was always observed within individuals clearly assigned to a given species. Nevertheless an ancient polymorphism (requiring 1 allele to be very rare) would, for example, explain why individual 23 was heterozygote at only 1 of 2 adjacent SNPs. Secondly, the evidence from sequence information towards introgressive hybridisation between $A$. marmorata and $A$. megastoma is backed up by the intermediate multilocus genotypes for the majority of individuals involved. Once again, such a pattern is difficult to explain through incomplete lineage sorting. However, at present we have insufficient data to explain the $A$. obscura mtDNA haplotype in a single $A$. megastoma.

Based on our premise that introgression has taken place, we found individuals with evidence for different levels of admixture rather than e.g. clear $F 1$ hybrids, a pattern that is not unexpected for otherwise distinct species between which hybridisation is likely to be local and/or rare. We attribute the fact that several pure individuals as well as possibly admixed individuals clustered with A. obscura microsatellite genotypes largely to the low sample size for this species $(n=7)$, which precluded a cluster with a pronounced species-specific genetic signature. Given the limited number of nuclear markers employed (1 sequence and 6 microsatellites), our power to reveal fine-scale patterns of introgression was clearly limited. However, the main purpose of this work was purely to document the likely existence of admixed individuals, to support the evidence of shared spawning areas between the species studied. The behaviour of the putatively admixed eel that was tagged also confirmed that they exhibit the same diel vertical migration behaviour as their parental species.

Previous morphological (Ege 1939) and genetic studies (Aoyama 2009 and references therein) never grouped A. marmorata and A. megastoma close enough to presume hybridisation similar to the 2 Atlantic eel sister species (e.g. Pujolar et al. 2014, Wielgoss et al. 2014). However, cross-fertilizations of anguillid eel species were possible even between distantly related species, although the larvae only survived for 5 to 30 d (Lokman \&Young 2000, Okamura et al. 2004, Burgerhout et al. 2011). The HardyWeinberg equilibrium across microsatellite genotypes suggests single panmictic gene pools for each of the species studied on Gaua Island. Further analy- 
ses of both species throughout the WSP will reveal whether the putative introgression is restricted to eels from this area, or is more widespread over their mutual distribution range. Theoretically, possible eastern populations of both species may also share similar spawning areas, as A. megastoma occurs on Pitcairn Island (Ege 1939) and A. marmorata may even infrequently reach the Galápagos Archipelago (McCosker et al. 2003).

After the Sargasso Sea and the western North Pacific Mariana spawning areas, the findings of the present study appear to be the third example of 2 species of Anguilla spawning at the same location. Pujolar et al. (2014) argued that low genetic differentiation between closely related and hybridising species may be common among marine fishes with large population sizes. The present study also confirms previous evidence that genetic diversity in Anguilla is generally high, involving significant amounts of variation shared between species (for example, indicated by high cross-species microsatellite amplification success rates; Wielgoss et al. 2008) despite significant differentiation. In this respect, eels could serve as model organisms for the study of hybridisation in migratory marine fish species and its biological implications.

\section{Oceanic migration behaviour}

Although the present study was able to obtain new spawning migration data from 2 more eels, it also highlighted the difficulty in obtaining large migratory-stage silver eels for use in tagging studies (see also Schabetsberger et. al 2013). Tags on slightly wounded and smaller fish were lost after less than 1 mo of deployment, except for an A. marmorata (Eel 1), who kept the tag for the full pre-programmed 3 mo in 2012 despite bearing a hooking mark. No data were retrieved from eels previously kept in a holding tank prior to tagging, emphasizing the importance of short handling times to avoid initial stress that may result in disorientation or the cessation of long-distance migration behaviour. However, even when the tags stayed on for only short periods of time, the eels showed similar initial diel vertical migration patterns to the fish that retained their tags much longer.

Distinct diel vertical migrations between nighttime depths of 160-300 m to daytime depths around $750 \mathrm{~m}$ were observed in both species. The eels descended within 2 to $3 \mathrm{~h}$, exposing themselves to temperature changes of more than $16^{\circ} \mathrm{C}$ twice a day. They seldom descended below $850 \mathrm{~m}$ and $5^{\circ} \mathrm{C}$. Although there may be unknown reasons to not descend deeper, this could be a threshold where predation risk of diving predators from above is traded off against maintenance of minimum metabolism for migration. Likely, at great depths and $<5^{\circ} \mathrm{C}$, their movements are slowed down considerably (Vøllestad \& Jonsson 1986, Methling et al. 2012). Only during 2012 did a wounded A. megastoma stay at $980 \mathrm{~m}$ depth and $3.5^{\circ} \mathrm{C}$ for 2 consecutive days, probably resting at the bottom after tagging (Schabetsberger et al. 2013).

After release, most eels progressively lowered their daytime migration depths from around $500 \mathrm{~m}$ to reach maximum migration depths within 1 to $2 \mathrm{wk}$, corresponding to an average daily increase of approximately $20 \mathrm{~m}$, although faster descents did occur. It is unknown whether they slowly moved away from the island with their dives restricted by the island's slope or whether they gradually adapted to high pressure and low temperatures in the open water. The latter is more likely, given that the average migration speed $\left(\sim 10 \mathrm{~km} \mathrm{~d}^{-1}\right)$ was similar for short and long distances covered. As the ocean floor near Gaua drops steeply, the eels can reach waters of more than $1000 \mathrm{~m}$ depth within a day after release.

Distinct lunar cycles in the upper limits of the eel migration depths were observed for both species. The high transparency of the clear tropical ocean may render this adjustment of upper migration depth to lunar cycle more discernible, but it may also be found in temperate eels once they reach tropical latitudes. We earlier interpreted this behaviour as being a mechanism for avoidance of predators, such as sharks and swordfish, hunting deeper during full moon periods (Schabetsberger et al. 2013). The eels usually avoided the upper $100 \mathrm{~m}$, suggesting that such shallow waters may be too dangerous for migration even at night (Schabetsberger et al. 2013 and references therein).

If tropical eels indeed have the ability for multiple spawning as appears to be the case for A. japonica (Tsukamoto et al. 2011), they must continue hiding from predators once they have reached the spawning area. To remain in shallow water during the day would probably increase the risk of being preyed on before the successive release of a second batch of eggs. The 2 eels that kept their tags until the pre-programmed release dates did not move to shallow water. Therefore, it is possible that they continued to exhibit pronounced diel vertical migrations while searching for spawning aggregations or even after releasing the first batch of eggs. Although it is unknown whether they even form distinct aggrega- 
tions, oceanic predators could still cue in on eels gathering in a certain area at a particular depth.

Alternatively, remaining at shallower depths during periods of active spawning might facilitate successful final maturation of the eggs allowing a period of continuous spawning over several days, which would be consistent with the behaviour of the $A$. megastoma (Eel 8) in the present study. However, its sudden shift to shallow depth 1 wk prior to early popup could have different explanations for what occurred. It could have been preyed upon during full moon (Béguer-Pon et al. 2012) and the tag may be showing the foraging depths of a predator that ate it. Alternatively, the eel could have been weakened or was about to die and stopped descending below 400 $m$ depth, but we cannot exclude the possibility that the eel was still strong and came up for reproduction. Future tagging studies will help to shed light on how eels behave during spawning.

The overall pop-up area was reached after 3 mo of oceanic migration based on Eels 1 and 8, corresponding to a migration speed of $\sim 10 \mathrm{~km} \mathrm{~d}^{-1}$. Assuming that Eel 6 with the tag attached for 5 mo did not approach the area at a slower pace than Eels 1 and 8, it could have remained in the spawning area for another 2 mo. It may have been unsuccessfully searching for mates during this time, or it may have been involved in spawning activities over an extended period of time while still performing diel vertical migrations. After the fourth new moon period in the ocean, it perceptibly decreased its lower and upper migration depths, but whether this is an indication of the first spawning event remains unknown.

\section{Sympatric spawning area}

The fact that $15 \%$ of the eels examined on Gaua Island were possibly admixed individuals between A. marmorata and A. megastoma shows that these 2 species may frequently interbreed and that their spawning areas in the ocean likely overlap. Tags from both species popped up in the same general area, irrespective of being attached for either 3 or 5 mo during consecutive years. Compared to the scale over which spawning occurs for the Atlantic eels in the Sargasso Sea (McCleave et al. 1987), the pop-up locations were clearly close enough to be part of an anguillid spawning area. Additionally, some of the smallest leptocephali collected so far (A. marmorata, 19, 24 and $>35 \mathrm{~mm}$; A. megastoma $42.8 \mathrm{~mm}$, Kuroki et al. 2008) were located to the southeast of the A. marmorata pop-up locations, and very close to the pop-up location of A. megastoma (Fig. 4). These 3 lines of evidence suggest that both species may spawn across this area.

This potential spawning area is located at latitudes where there are several oceanographic features that could provide seamarks for migrating eels. Firstly, the pop-up area was within the high-salinity core present between about 100 and $200 \mathrm{~m}$ depths at the upper nighttime migration depth of eels. This wellestablished oceanographic feature is subducted in the centre of the South Pacific subtropical gyre (Johnson \& McPhaden 1999) and may form a relatively constant reference point that the eels could use to find their spawning area, assuming that they spawn at similar depths as Japanese eels (estimated to be around 160 to $200 \mathrm{~m}$, Tsukamoto et al. 2011). Secondly, salinity fronts near the surface are likely present above $75 \mathrm{~m}$ depth at the edges of the shallow western Pacific 'fresh pool' (Delcroix et al. 1987, Delcroix \& Picaut 1998, Roden 1998, Miller et al. 2006). These shallow salinity fronts at the border between the SEC and the SECC (Fig. 7) may not be the primary seamark if eels seldom ascend above $100 \mathrm{~m}$ depths, but data about eel behaviour in their spawning areas are as yet insufficient to make any conclusions. Both types of salinity features are also present in the Japanese eel spawning area (Aoyama et al. 2014). Thirdly, the 2 currents in the area flowing in opposite directions during some seasons could serve as additional seamarks of specific spawning locations. Finally, eels have a geomagnetic sense, which might be used to locate the general region for reproduction (Tsukamoto 2009, Durif et al. 2013 and references therein). An oceanographic survey coupled with collections of eggs or newly hatched leptocephali will be required to learn more about the actual spawning sites and the possible oceanographic seamarks used to locate them.

A spawning area in this region could result in a variety of transport routes for leptocephali due to the dynamic seasonal and annual changes in the 2 currents (Delcroix et al. 1987, Delcroix \& Picaut 1998, Hénin et al. 1998, Chen \& Qiu 2004). For example, the strength and position of the SECC can vary throughout the year and is usually weaker or almost absent between May and September (Chen \& Qiu 2004), possibly causing some leptocephali to be retained in the area. Furthermore, inter-annual variability in latitudinal positions and flow rates of both current systems can be coupled to El Niño-Southern Oscillation (ENSO) events (Reverdin et al. 1994, Delcroix 1998, Johnson et al. 2000, Ganachaud et al. 2007). During El Niño years, the western warm pool spreads to the 
east and the SECC becomes stronger, while the SEC weakens. Vice versa, during La Niña years, the eastern cold tongue spreads farther to the west and consequently the flow of the SEC increases (Johnson et al. 2000). Hence the variable flows in between the 2 current systems could result in leptocephali going in various directions, thus providing recruitment to many areas of that region of the WSP over time. In this context, it would be interesting to relate recruitment on different archipelagos to ENSO events.

This potential spawning area may not be the only one for these 2 tropical anguillid eels in the WSP. A genetic screening may clarify whether eels from the Solomons, Vanuatu, Fiji and New Caledonia are panmictic or have different spawning areas. Morphological studies (Ege 1939, Watanabe et al. 2011) suggest that additional spawning populations exist farther east. More research to collect small leptocephali is needed to confirm the location of the spawning area that is indicated by the present study and to locate where other spawning areas may exist. Future studies should also extend tagging experiments all the way to eastern Polynesia. Concurrently with scientific research, awareness campaigns and conservation efforts should be developed throughout the region to protect these eels from commercial harvest until more information is available about their life histories and population trends (Pickering 2014).

Acknowledgements. We dedicate this paper to the memory of Jaak Tambets, who devoted his life to the protection of nature. Field work was carried out under a permit issued by the Department of Environmental Protection and Conservation (DEPC, 1 March 2013) and in concordance with the code of ethics for foreign researchers from the Government of Vanuatu. This study was funded through a grant from the International Program of the Austrian Academy of Sciences. We thank Microwave Telemetry in Columbia, MD, for free tags and technical advice. Satellite time and 3 transmitters were provided by grant 212133 'Eeliad' (European Union, FP7). Albert Williams, Director of the DEPC, supported our field operations. Chiefs Victor Wotias and Paul Lazarus gave permission to work on Gaua and guided our team at Lake Letas. The Togase family looked after us in their home, Hamson Salvemal was our chief guide during both years of field work, and Adam Basil and his group of fishermen provided eels for tagging. Hans Peter Comes, Philippe Borsa, and 5 anonymous reviewers provided numerous critical comments. We are grateful to all the people who were involved in making this study possible.

\section{LITERATURE CITED}

Aarestrup K, Økland F, Hansen MM, Righton D and others (2009) Oceanic spawning migration of the European eel (Anguilla anguilla). Science 325:1660

Albert V, Jónsson B, Bernatchez L (2006) Natural hybrids in
Atlantic eels (Anguilla anguilla, A. rostrata): evidence for successful reproduction and fluctuating abundance in space and time. Mol Ecol 15:1903-1916

Anderson EC, Thompson EA (2002) A model-based method for identifying species hybrids using multilocus genetic data. Genetics 160:1217-1229

Aoyama J (2009) Life history and evolution of migration in catadromous eels (genus Anguilla). Aqua-Biosci Monogr 2:1-42, doi: 10.5047/absm.2009.00201.0001

Aoyama J, Wouthuyzen S, Miller MJ, Inagaki T, Tsukamoto K (2003) Short-distance spawning migration of tropical freshwater eels. Biol Bull (Woods Hole) 204:104-108

Aoyama J, Watanabe S, Miller MJ, Mochioka N, Otake T, Yoshinaga T, Tsukamoto K (2014) Spawning sites of the Japanese eel in relation to oceanographic structure and the West Mariana Ridge. PLoS ONE 9:e88759

Arai T (2014) Do we protect freshwater eels or do we drive them to extinction? Springer Plus 3:534

Bandelt HJ, Forster P, Röhl A (1999) Median-joining networks for inferring intraspecific phylogenies. Mol Biol Evol 16:37-48

Béguer-Pon M, Benchetrit J, Castonguay M, Aarestrup K, Campana SE, Stokesbury MJW, Dodson JJ (2012) Shark predation on migrating adult American eels (Anguilla rostrata) in the Gulf of St. Lawrence. PLoS ONE 7:e46830

Bruen TC, Philippe H, Bryant D (2006) A simple and robust statistical test for detecting the presence of recombination. Genetics 172:2665-2681

Burgerhout E, Brittijn SA, Kurwie T, Decker P and others (2011) First artificial hybrid of the eel species Anguilla australis and Anguilla anguilla. BMC Dev Biol 11:16

Chen S, Qiu B (2004) Seasonal variability of the South Equatorial Countercurrent. J Geophys Res 109:C08003, doi: 10.1029/2003JC002243

Chow S, Kurogi H, Mochioka N, Kaji S, Okazaki M, Tsukamoto K (2009) Discovery of mature freshwater eels in the open ocean. Fish Sci 75:257-259

Delcroix T (1998) Observed surface oceanic and atmospheric variability in the tropical Pacific at seasonal and ENSO timescales: a tentative overview. J Geophys Res 103:18611-18633

Delcroix T, Picaut J (1998) Zonal displacement of the western equatorial Pacific 'fresh pool'. J Geophys Res 103:1087-1098

Delcroix T, Eldin G, Hénin C (1987) Upper ocean water masses and transports in the western tropical Pacific $\left(165^{\circ} \mathrm{E}\right)$. J Phys Oceanogr 17:2248-2262

Dewar H, Prince ED, Musyl MK, Brill RW and others (2011) Movements and behaviours of swordfish in the Atlantic and Pacific Oceans examined using pop-up satellite archival tags. Fish Oceanogr 20:219-241

Durif CMF, Browman HI, Phillips JB, Skiftesvik AB, Vøllestad LA, Stockhausen HH (2013) Magnetic compass orientation in the European eel. PLoS ONE 8:e59212

Ege V (1939) A revision of the genus Anguilla Shaw. DanaReport 16:8-256

Excoffier L, Laval G, Schneider S (2005) Arlequin ver. 3.0: an integrated software package for population genetics data analysis. Evol Bioinform Online 1:47-50

Falush D, Stephens M, Pritchard JK (2003) Inference of population structure using multilocus genotype data: linked loci and correlated allele frequencies. Genetics 164: 1567-1587

Gagnaire PA, Minegishi Y, Zenboudji S, Valade P, Aoyama J, Berrebi P (2011) Within population structure high- 
lighted by differential introgression across semipermeable barriers to gene flow in Anguilla marmorata. Evolution 65:3413-3427

Ganachaud A, Kessler W, Wijffels S, Ridgway K and others (2007) Southwest Pacific Ocean Circulation and Climate Experiment (SPICE) - Part I. Scientific background International CLIVAR Project Office, CLIVAR Publication Series No. 111, NOAA OAR Special Report. NOAA/OAR/PMEL, Seattle, WA

Goudet J (2002) FSTAT: a program to estimate and test gene diversities and fixation indices. Version 2.9.3.2. Available at www2.unil.ch/popgen/softwares/fstat.htm

Guindon S, Dufayard JF, Lefort V, Anisimova M, Hordijk W, Gascuel O (2010) New algorithms and methods to estimate maximum-likelihood phylogenies: assessing the performance of PhyML 3.0. Syst Biol 59:307-321

Harrigan RJ, Mazza ME, Sorenson MD (2008) Computation vs. cloning: evaluation of two methods for haplotype determination. Mol Ecol Resour 8:1239-1248

Hénin CJ, du Penhoat Y, Ioualalen M (1998) Observations of the sea surface salinity in the western Pacific fresh pool: large scale changes in 1992-1995. J Geophys Res 103: 7523-7536

Huson DH, Bryant D (2006) Application of phylogenetic networks in evolutionary studies. Mol Biol Evol 23:254-267

Ishikawa S, Tsukamoto K, Nishida M (2001) Characterization of microsatellite loci from the Japanese eel Anguilla japonica. Mol Ecol Notes 1:140-142

Ishikawa S, Tsukamoto K, Nishida M (2004) Genetic evidence for multiple geographic populations of the giant mottled eel Anguilla marmorata in the Pacific and Indian oceans. Ichthyol Res 51:343-353

Jellyman DJ (2003) The distribution and biology of the South Pacific species of Anguilla. In: Aida K, Tsukamoto $\mathrm{K}_{\text {, }}$ Yamauchi K (eds) Eel biology. Springer, Tokyo, p 275292

Jellyman D, Tsukamoto K (2002) First use of archival transmitters to track migrating freshwater eels Anguilla dieffenbachii at sea. Mar Ecol Prog Ser 233:207-215

Jellyman D, Tsukamoto K (2005) Swimming depths of offshore migrating longfin eels Anguilla dieffenbachii. Mar Ecol Prog Ser 286:261-267

Jellyman D, Tsukamoto K (2010) Vertical migrations may control maturation in migrating female Anguilla dieffenbachii. Mar Ecol Prog Ser 404:241-247

Johnson GC, McPhaden MJ (1999) Interior pycnocline flow from the subtropical to the equatorial Pacific Ocean. J Phys Oceanogr 29:3073-3089

Johnson GC, McPhaden MJ, Rowe GD, McTaggart KE (2000) Upper equatorial Pacific Ocean current and salinity variability during the 1996-1998 El Niño-La Niña cycle. J Geophys Res 105:1037-1053

Keith P, Marquet G, Lord C, Kalfatak D, Vigneux E (2011) Vanuatu freshwater fish and crustaceans. Societé française d'ichtyologie, Paris

Kimura S, Tsukamoto K (2006) The salinity front in the North Equatorial Current: a landmark for the spawning migration of the Japanese eel (Anguilla japonica) related to the stock recruitment. Deep-Sea Res II 53:315-325

Kleckner RC, McCleave JD (1988) The northern limit of spawning by Atlantic eels (Anguilla spp.) in the Sargasso Sea in relation to thermal fronts and surface water masses. J Mar Res 46:647-667

Kuroki M, Aoyama J, Miller MJ, Watanabe S and others (2008) Distribution and early life-history characteristics of anguillid leptocephali in the western South Pacific. Aust J Mar Freshw Res 59:1035-1047

Kuroki M, Aoyama J, Miller MJ, Yoshinaga T, Shinoda A, Hagihara S, Tsukamoto K (2009) Sympatric spawning of Anguilla marmorata and Anguilla japonica in the western North Pacific. J Fish Biol 74:1853-1865

Kuroki M, Aoyama J, Miller MJ, Yoshinaga T, Watanabe S, Tsukamoto K (2012) Offshore spawning of the newly discovered anguillid species Anguilla luzonensis (Teleostei: Anguillidae) in the western North Pacific. Pac Sci 66: 497-507

Librado P, Rozas J (2009) DnaSP v5: a software for comprehensive analysis of DNA polymorphism data. Bioinformatics 25:1451-1452

Lokman PM, Young G (2000) Induced spawning and early ontogeny of New Zealand freshwater eels (Anguilla dieffenbachia and A. australis). N Z J Mar Freshw Res 34: 135-145

Manabe R, Aoyama J, Watanabe K, Kawai M, Miller MJ, Tsukamoto K (2011) First observations of the oceanic migration of Japanese eel, from pop-up archival transmitting tags. Mar Ecol Prog Ser 437:229-240

McCleave JD, Kleckner RC, Castonguay M (1987) Reproductive sympatry of American and European eels and implications for migration and taxonomy. In: Dadswell MJ, Klauda RJ, Moffitt C, Saunders RL, Rulifson RA, Cooper JE (eds) Common strategies of anadromous and catadromous fishes. American Fisheries Society, Boston, MA, p 286-297

McCosker JE, Bustamante RH, Wellington GM (2003) The freshwater eel, Anguilla marmorata, discovered in Galápagos. Notic Galápagos 62:2-6

Methling C, Steffensen JF, Skov PV (2012) The temperature challenges on cardiac performance in winter-quiescent and migration-stage eels Anguilla anguilla. Comp Biochem Physiol A Mol Integr Physiol 163:66-73

Miller MJ, Aoyama J, Mochioka N, Otake T and others (2006) Geographic variation in the assemblages of leptocephali in the western South Pacific. Deep-Sea Res I 53: 776-794

Miller MJ, Kimura S, Frieland KD, Knights B, Kim H, Jellyman DJ, Tsukamoto K (2009) Review of ocean-atmospheric factors in the Atlantic and Pacific Oceans influencing spawning and recruitment of anguillid eels. Am Fish Soc Symp 69:231-249

Minegishi Y, Aoyama J, Tsukamoto K (2008) Multiple population structure of the giant mottled eel Anguilla marmorata. Mol Ecol 17:3109-3122

Munk P, Hansen MM, Maes GE, Nielsen TG and others (2010) Oceanic fronts in the Sargasso Sea control the early life and drift of Atlantic eels. Proc R Soc Lond B Biol Sci 277:3593-3599

Okamura A, Zhang H, Utoh T, Akazawa A and others (2004) Artificial hybrid between Anguilla anguilla and $A$. japonica. J Fish Biol 64:1450-1454

Okamura A, Yamada Y, Yakouchi K, Horie N and others (2007) A silvering index for the Japanese eel Anguilla japonica. Environ Biol Fishes 80:77-89

Pickering T (2014) Unlocking the secrets of South Pacific tropical freshwater eels. SPC Fish Newsl 142:30-32

Posada D, Crandall KA (1998) Modeltest: testing the model of DNA substitution. Bioinformatics 14:817-818

Pritchard JK, Stephens M, Donnelly P (2000) Inference of population structure using multilocus genotype data. Genetics 155:945-959 
Pujolar JM, Jacobsen MW, Als TD, Frydenberg J and others (2014) Assessing patterns of hybridization between North Atlantic eels using diagnostic single-nucleotide polymorphisms. Heredity 112:627-637

Reverdin G, Frankignoul E, Kestenare E, McPhaden MJ (1994) Seasonal variability in the surface currents of the equatorial Pacific. J Geophys Res 99:20323-20344

Righton D, Aarestrup K, Jellyman D, Sébert P, van den Thillart G, Tsukamoto K (2012) The Anguilla spp. migration problem: 40 million years of evolution and two millennia of speculation. J Fish Biol 81:365-386

Roden G (1998) Upper ocean thermohaline, oxygen, nutrient, and flow structure near the dateline in the summer of 1993. J Geophys Res 103:12919-12939

Rousset J (2008) genepop'007: a complete re-implementation of the genepop software for Windows and Linux. Mol Ecol Resour 8:103-106

Sambrook J, Fritsch EF, Maniatis T (1989) Molecular cloning: a laboratory manual, 2nd edn. Cold Spring Harbor Laboratory Press, Cold Spring Harbor, NY

Schabetsberger R, Økland F, Aarestrup K, Kalfatak D and others (2013) Oceanic migration behaviour of tropical Pacific eels from Vanuatu. Mar Ecol Prog Ser 475: $177-190$

Schmidt J (1922) The breeding places of the eel. Philos Trans R Soc Lond B Biol Sci 211:179-208

Stephens M, Donnelly P (2003) A comparison of Bayesian methods for haplotype reconstruction from population genotype data. Am J Hum Genet 73:1162-1169

Tamura K, Stecher G, Peterson D, Filipski A, Kumar S (2013) MEGA6: Molecular Evolutionary Genetics Analysis version 6.0. Mol Biol Evol 30:2725-2729

Toews DPL, Brelsford A (2012) The biogeography of mitochondrial and nuclear discordance in animals. Mol Ecol

Editorial responsibility: Philippe Borsa, Montpellier, France

$$
\text { 21:3907-3930 }
$$

Tsukamoto K (2009) Oceanic migration and spawning of anguillid eels. J Fish Biol 74:1833-1852

Tsukamoto K, Chow S, Otake T, Kurogi H and others (2011) Oceanic spawning ecology of freshwater eels in the western North Pacific. Nat Commun 2:179

Vøllestad LA, Jonsson B (1986) Life-history characteristics of the European eel Anguilla anguilla in the Imsa River, Norway. Trans Am Fish Soc 115:864-871

Wahlberg M, Westerberg H, Aarestrup K, Feunteun E, Gargan P, Righton D (2014) Evidence of marine mammal predation of the European eel (Anguilla anguilla L.) on its marine migration. Deep-Sea Res I 86:32-38

Watanabe S, Aoyama J, Miller MJ, Ishikawa S, Feunteun E, Tsukamoto K (2008) Evidence of population structure in the giant mottled eel, Anguilla marmorata, using total number of vertebrae. Copeia 2008:680-688

Watanabe S, Miller MJ, Aoyama J, Tsukamoto K (2011) Analysis of vertebral counts of the tropical anguillids, Anguilla megastoma, A. obscura, and A. reinhardtii, in the western South Pacific in relation to their possible population structure and phylogeny. Environ Biol Fishes 91:353-360

Wielgoss S, Wirth T, Meyer A (2008) Isolation and characterization of 12 dinucleotide microsatellites in the European eel, Anguilla anguilla L., and tests of amplification in other species of eels. Mol Ecol Resour 8:1382-1385

Wielgoss S, Gilabert A, Meyer A, Wirth T (2014) Introgressive hybridization and latitudinal admixture clines in North Atlantic eels. BMC Evol Biol 14:61

Xiao-Ling G, Sheng-Jie R, Shu-Quiang C, Zhi-Ying J (2009) Highly polymorphic microsatellite loci from the giant mottled eel (Anguilla marmorata). Mol Ecol Resour 9: 1544-1547

Submitted: May 15, 2014; Accepted: November 28, 2014

Proofs received from author(s): January 16, 2015 